Acta Universitatis Nicolai Copernici • Pedagogika XXXIV/2/2017

Nauki Humanistyczno-Społeczne • Zeszyt 440

DOI: http://dx.doi.org/10.12775/AUNC_PED.2017.015

Lidia Marszałek

Pedagogium WSNS w Warszawie

\title{
RE-KONSTRUKCJA DIALOGU POKOLEŃ W RZECZYWISTOŚCI KULTURY PREFIGURATYWNEJ
}

\section{Wprowadzenie - podstawowe założenia koncepcji kultury Margaret Mead}

Wargaret Mead - amerykańska przedstawicielka i współtwórczyni konfiguracjonizmu (szkoły kultury i osobowości) na podstawie swoich badań wyodrębniła trzy typy kultur: postfiguratywną, kofiguratywną i prefiguratywną. Pierwsza z nich odpowiada modelowi kultury tradycyjnej, w której młode pokolenie wzoruje się na starszych w budowaniu i kształtowaniu swojego przyszłego życia. Dzieci są wychowywane według oczekiwań osób dorosłych, a na swoje pytania - dlaczego mają tak postępować, uzyskują odpowiedzi typu „bo tak trzeba”, „bo ja tak ci każę”, „bo zawsze tak robiliśmy”. Proces kulturowego uczenia się oparty jest na autorytecie pochodzącym z przeszłości. Ludzie żyją w wielopokoleniowych rodzinach, gdzie najstarsza generacja darzona jest niezwykłym posłuchem i szacunkiem, starsi zaś dbają o to, by życie młodych biegło ustalonymi od wieków torami. Starsze pokolenie nie chce dopuścić do jakichkolwiek zmian i zachować względnie stałą ciągłość. Tym samym przekazują bardzo często obowiązek kultywowania pewnych tradycji i norm. 
Kultura kofiguratywna powstaje wskutek rozpadu kultury postfiguratywnej i opiera się na założeniu, iż młodzi i starsi są dla siebie równorzędnymi partnerami, a ich wzajemne stosunki cechuje tolerancja i szacunek, dominującym zaś wzorem dla członków społeczeństwa jest zachowanie rówieśników. Kultury kofiguratywne opierają się na takim doświadczeniu młodych pokoleń, które nie ma odpowiednika w doświadczeniu rodziców, dziadków i innych starszych osób z bezpośredniego otoczenia. Zadaniem młodych ludzi jest odnalezienie nowych stylów zachowania, opartych na ich osobistym doświadczeniu i przekazanie je jako wzór innym rówieśnikom. Jednak starsze pokolenia nadal odgrywają rolę podstawową w tym sensie, że określają granice i formy, w których kofiguracja może wystąpić w zachowaniu młodych.

Kultura prefiguratywna to model, w którym młodzi dzięki łatwiejszemu przyswajaniu sobie nowych wartości szybciej podążają za zmianami społecznymi, zyskując niezależność od swych rodziców, a ci z kolei muszą uczyć się od swoich dzieci i wnuków. Współcześnie w niektórych obszarach życia wiedza dzieci znacznie przekracza wiedzę osób dorosłych, szczególnie starszego pokolenia. Młodzi ludzie nie łudzą się, że istnieją jeszcze gdzieś na świecie dorośli, od których mogliby się dowiedzieć, co powinni dalej robić w życiu. Model prefiguratywny zakłada, że starsi uznają niezależność dzieci i młodzieży, uczą się od nich postaw i zachowań, których nie nabyli w swoim dzieciństwie ze względu na akcelerację rytmu współczesnego życia. Starsze pokolenie nie może liczyć na to, że w życiu ich dzieci i wnuków powtórzą się doświadczenia przeżyte przez nich wiele lat temu. Stąd też w postawie starszego pokolenia musi nastąpić odejście i uwolnienie od przeszłości i od starych form zarządzania wychowaniem ${ }^{1}$.

1 Por. M. Mead, Kultura i tożsamość. Studium dystansu międzypokoleniowego, tłum. J. Hołówka, Warszawa 2000; T. Szkudlarek, B. Śliwerski, Wyzwania pedagogiki krytycznej i antypedagogiki, Kraków 1992, s. 117. 


\section{Specyfika współczesnego świata młodych ludzi}

Początek XXI w. przyniósł wiele zmian nie tylko ekonomicznych i gospodarczych, lecz przede wszystkim mających charakter społeczny. Efekty tych zmian widoczne są m.in. w systemach wartości - uniwersalne wartości tracą na znaczeniu w poglądach współczesnych młodych ludzi. Powszechne staje się podążanie za posiadaniem dóbr materialnych i ich konsumpcją, co następuje kosztem wartości moralnych, etycznych, uczuciowych oraz intelektualnych. Normy, wartości, wzory zachowania ulegają zmianom oraz dostosowują się do dzisiejszego świata.

Widoczne są też skutki współczesności, które dość silnie wpływają na sytuację dzisiejszej rodziny: osłabia się ich kondycja biologiczna i psychiczna, uwidocznia się erozja systemów wartości rodzinnych. Zmianie ulega charakter więzi w rodzinie, kontakty stają się luźniejsze, wzrasta indywidualizm, słabnie wpływ norm obyczajowych i religijnych. Zauważalny jest wzrost liczby rozwodów oraz zjawisk patologii w rodzinie ${ }^{2}$. Obserwowane są tendencje zwiększania się liczby rodzin małych (dwupokoleniowych) w miejsce rodzin wielopokoleniowych, a w ślad za tym podąża osłabienie więzi emocjonalnych pomiędzy krewnymi mieszkającymi osobno ${ }^{3}$.

Faktem jest, iż współczesny świat niesie ze sobą wiele zagrożeń dla prawidłowych zjawisk socjalizacyjnych w rodzinie i wciąż narasta liczba czynników, stanowiących zagrożenie dla prawidłowego jej funkcjonowania. Niewydolność wychowawcza, odrywanie się od tradycji, bezrobocie, przemoc, patologie społeczne, osłabienie funkcji socjalizacyjno-wychowawczej coraz bardziej osłabiają kondycję rodziny. Nie potrafi ona odpowiadać na potrzeby dzieci, coraz powszechniejsza staje się nieobecność psychiczna dorosłych w świecie latorośli, obustronna hibernacja emocjonalna, załamanie się dialogu między dorosłymi a dziećmi. Konieczność zaspokojenia podstawowych potrzeb ro-

2 P. Sztompka, Socjologia zmian społecznych, Kraków 2005, s. 82-86.

3 T. Szlendak, Socjologia rodziny. Ewolucja, historia, zróżnicowanie, Warszawa 2011, s. 367-368. 
dziny zmusza rodziców do wysiłku, zabiera czas i energię, powoduje wyczerpanie codziennym tempem życia, nierzadko konflikty i oskarżenia o zaniedbywanie wzajemnych potrzeb.

Media (telewizja, internet) tworzą gęstą sieć wpływów, w którą uwikłany jest współczesny człowiek. Zasypywany informacjami, nie jest w stanie już ich porządkować i wartościować. Media zniekształcają percepcję rzeczywistości przez człowieka, co prowadzi do zagubienia w realnym świecie, utrudnia oddzielanie prawdy od fałszu, samodzielne myślenie i właściwą ocenę rzeczywistości. Zmieniły one styl życia, system wartości i zachowań ludzi. Serwowany odbiorcy przekaz, promując materialistyczną i hedonistyczną mentalność, ma go zachęcić do sięgania po to, co najlepsze, korzystania z tego, co dostępne. Najwyższą wartością wydaje się źle rozumiana wolność do korzystania ze wszystkich dobrodziejstw cywilizacji. Tymczasem wolność ta najczęściej bywa iluzją, opartą na wymogu przystosowania się do przymusu obiegowych schematów myślenia, wartościowania, postępowania. Przymus ten nie pozwala na refleksję, na pytania, co jest dobre, a co złe; co słuszne, a co niesłuszne. Wyrokowanie o dobru i złu zaczyna odbywać się nie według prawdziwych wartości czynów, ale według korzyści, chwilowego sukcesu czy przyjemności.

Bezpośredni odbiorcy mediów wystawieni są na wielość i sprzeczność informacji, na agresywne treści, przekazywane coraz bardziej jawnie i bezwzględnie, zniekształcające prawdziwy obraz życia, stosunków międzyludzkich i człowieka jako osoby. Rewolucja informacyjna, zamiast uporządkować świat, uczyniła go jeszcze bardziej niezrozumiałym, zwłaszcza w sferze moralnej. Panujący pluralizm opinii, poglądów, przekonań, norm i wartości sprawia, że do młodych ludzi docierają niejednokrotnie sprzeczne lub niespójne treści, powodujące ich dezorientację. Kult tymczasowości, kulturowe zwrócenie się w stronę zachodu i bezkrytyczne czerpanie z jego wzorców, apoteoza pieniądza i konsumpcji, to rzeczywistość, w jakiej przyszło żyć dzisiejszym polskim rodzinom z małymi dziećmi. „Ludzkie reakcje pokazują, że media są czymś więcej niż tylko narzędziami. Media mogą wtargnąć w naszą przestrzeń osobistą [...] mogą wywoływać reakcje emocjonalne, wymagać koncentracji uwagi, zagrażać nam, wpływać na pamięć 
i zmieniać pojęcia tego, co naturalne. Media są pełnymi uczestnikami naszego świata społecznego i rzeczywistego"4.

Coraz częściej dzieci przestają interesować się programami telewizyjnymi, stworzonymi specjalne dla nich. Już w wieku przedszkolnym poszukują programów przeznaczonych dla osób dorosłych. Anna Przecławska podkreśla, że „młodzi widzowie bardzo wcześnie opuszczają świat dziecięcych przeżyć i wyobrażeń, nie chcą oglądać programów przeznaczonych dla dzieci i młodzieży. Oglądają te same treści co dorośli i przejawiają podobne do dorosłych upodobania"5. Niepokojący jest też fakt, że przekazy prezentowane przez media elektroniczne oddziałują na postawy młodego człowieka znacznie silniej niż wzory, które przekazywane są przez dorosłych. Przekazy te zarówno informują, jak i kształtują poglądy oraz postawy życiowe, gdyż „przemawiają jednocześnie językiem totalnym, tj. słowem, dźwiękiem, obrazem, ruchem, wpływając na rozum, wyobraźnie i uczucia"6.

Preferowane przez media wzorce zachowania charakteryzują się nadmiernym eksponowaniem wartości zabawy, rozrywki, nieograniczonej wolności, łatwego sukcesu, tworzeniem swoistego kultu młodości - nawet osoby starsze akceptowane są tylko wtedy, gdy prezentują zachowania „promłodzieżowe” (starsza pani na motocyklu, wiekowy ojciec prezentujący wyjątkową sprawność fizyczną). Jednocześnie unikają one tematów, które pozwoliłyby na odniesienie się do problemów egzystencjalnych. Prowadzi to do zafałszowania obrazu świata, pomija najistotniejsze problemy, rodząc wizję odrealnioną, w której nie ma miejsca na trud, cierpienie, przemijanie, śmierć. „Problem i niebezpieczeństwo wynikające z niewłaściwego korzystania z mediów polega na tym, iż rzeczywistość kreowana przez media nie tylko nie pomaga człowiekowi w przezwyciężaniu [...] [dychotomii egzystencjalnych -

4 B. Reeves, C. Nass, Media i ludzie, tłum. H. Szczerkowska, Warszawa 2000, S. 294.

5 A. Przecławska, Sytuacja kulturalna współczesnego dziecka polskiego, „Problemy Opiekuńczo-Wychowawcze" 2001, nr 1, s. 15.

6 A. Lewek, Podstawy edukacji medialnej i dziennikarskiej, Warszawa 2003, s. 62 . 
L. M.], ale poprzez zamazywanie i przemilczanie czyni je jeszcze trudniejszymi do przeżycia"”.

Współcześnie dzieci z każdej strony poddane są wpływom środków masowego przekazu, zarówno programów telewizyjnych, jak i treści internetowych. W każdym domu jest przynajmniej jeden komputer, do którego dostęp ma każdy domownik. Internet stał się wszechstronnym i powszechnym źródłem informacji, dzięki temu wiele osób uważa go za bardzo pozytywne i wartościowe źródło. Niestety obok walorów i wartościowych treści Internet niesie ze sobą wiele niebezpieczeństw z powodu łatwego i niekontrolowanego dostępu do demoralizujących treści, takich jak: witryny pornograficzne czy propagujące rasizm, pogardę dla wartości humanistycznych, skrajne poglądy polityczne i terroryzm. Zagrożeniem jest również nawiązanie przez dziecko kontaktu z niepożądanymi, niebezpiecznymi osobami. Możliwy jest też częsty kontakt z obrazami zła i przemocy, prowadzący w efekcie do uodpornienia się na ból i krzywdę drugiego człowieka, do milczącej akceptacji oraz postawy przyzwolenia dla agresji i okrucieństwa. Niekorzystny wpływ na rozwój młodego człowieka wywiera także strumień informacji, który napływa zbyt szybko i w ilościach przekraczających naturalną zdolność mózgu do racjonalnej selekcji wiadomości na ważne i potrzebne oraz na bezwartościowe. Zauważalny jest również wzrost anonimowości w sieci, co zachęca do zachowań nieetycznych. Następuje wzajemnie odizolowanie się użytkowników od siebie, czego konsekwencją jest rozluźnienie więzi, często prowadzące do zerwania kontaktów z otoczeniem i własną rodziną. W szerszym kontekście może to prowadzić do zupełnej izolacji dzieci i młodzieży.

Poprzez internet coraz więcej osób ulega manipulacji. Ten proces dotyczy zarówno dorosłych, jak i dzieci w każdym wieku.

Internet zapewnia możliwość manipulacji różnej natury: ze względu na różne formy i sposoby angażowania zmysłów użytkownika; poprzez bierne epatowanie odbiorcy treścią zasobów sieciowych; poprzez aktywny kontakt przedstawiciela danej witryny z użytkownikiem w czasie rzeczy-

7 J. Kwiek, Faktyczne i wyimaginowane zagrożenia wynikające ze stosowania mediów, w: Media a edukacja, pod red. W. Strykowskiego, Poznań 1997, s. 92. 
wistym lub odroczonym; poprzez włączanie użytkownika w aktywność rozmaitych grupek doraźnie skupionych we wspólnym czasie i miejscu cyberprzestrzeni ${ }^{8}$.

Znajdując się w cyberprzestrzeni, nierzadko człowiek uwikłany jest w kontakty z tamtejszą rzeczywistością, w której nie potrafi określić, kim naprawdę jest osoba „po drugiej stronie ekranu”.

Nowe zjawiska społeczne, takie jak „smartfonizacja” czy „tabletyzacja”, zmieniły świat najmłodszego i średniego pokolenia. Dzieci w tym świecie czują się , jak ryby w wodzie" - świat z urządzeniami mobilnymi stał się ich naturalnym środowiskiem. Według raportu Smart Kids. Dzieci $w$ mobilnym świecie $82 \%$ badanych rodziców twierdzi, że ich dzieci korzystają z urządzeń mobilnych. Od ósmego roku życia w zasadzie wszystkie dzieci, niezależnie czy rodzic jest mobilny, czy nie, korzystają już z urządzeń mobilnych. Warto też zauważyć, że dzieci poniżej pierwszego roku życia, a więc niemowlaki, bawią się już smartfonami i tabletami, a wśród dzieci w wieku do dwóch lat penetracja urządzeń mobilnych to już od $38 \%$ do nawet $61 \%$. Dzieci zaczynają mieć już swoje urządzenia mobilne w wieku dwóch-trzech lat, a od 15 roku życia korzystają już praktycznie tylko z własnych urządzeń. Tylko 3\% rodziców, których dzieci używają smartfonów lub tabletów, wskazuje, że te nie są połączone $\mathrm{z}$ internetem. Im dzieci są starsze, tym częściej urządzenie ma dostęp do sieci. Wyniki badań wskazują, że 96-97\% urządzeń nawet najmłodszych dzieci ma dostęp do sieci. Dzieci w Polsce bardzo wcześnie zaczynają korzystać z urządzeń mobilnych: 15\% dzieci zaczyna korzystać ze smartfona lub tabletu przed ukończeniem drugiego roku życia. Do czwartego roku życia mobilnych jest już 61\% dzieci9 .

8 B. Siemieniecki, Manipulacja - media-edukacja, Toruń 2006, s. 196.

9 Raport Smart Kids. Dzieci w mobilnym świecie. Raport powstał na podstawie badania ilościowego zrealizowanego przez Mobile Institute na zlecenie Digital Virgo i CAMO CODE. W ramach badania ilościowego zebrano opinie 714 rodziców. Wykorzystano responsywne ankiety CAWI (Computer-Assisted Web Interview) emitowane na stronach WWW, w szczególności na blogach parentingowych i w kanałach komunikacji PR Calling i Dworzynska.com. Badanie przeprowadzono w okresie grudzień 2015-luty 2016 r. 
Faktem jednak jest, że niemal bezustanne korzystanie przez dzieci ze wszystkich możliwych mediów i urządzeń im dedykowanych (komputerów, laptopów, tabletów, smartfonów) ogranicza czas na rozmowy rodzinne, bezpośrednie kontakty dorosłych i dzieci, wspólne spędzanie czasu wolnego. Dzieci coraz mniej czasu przeznaczają na pracę na rzecz rodziny, domu, na zabawy z rówieśnikami, nawet na rozwijanie własnych zainteresowań i zdolności. Redukcji ulegają także inne formy uczestnictwa dziecka w kulturze, np. chodzenie do kina, teatru, udział w zajęciach pozaszkolnych.

\section{Starsze pokolenie w rodzinie - załamanie dialogu}

Stosunki między dziadkami a wnukami są bardzo ważne zarówno dla jednej, jak i dla drugiej strony. Potrzebują siebie nawzajem. Jedni i drudzy mogą zaspokajać swoje potrzeby. Więź, jaka ich łączy, zależy od intensywności kontaktów. Im częstsze kontakty, tym więź jest silniejsza. Budowaniu tej więzi sprzyjają różnego rodzaju formy spędzania wspólnego czasu. Rodzice w gonitwie za zabezpieczeniem potrzeb materialnych rodziny często zapominają (bądź nie chcą pamiętać) o tradycjach, wyższych wartościach, które powinny być wpajane dzieciom. Dziadkowie zawsze o tym przypomną lub wszystko zorganizują tak, jak zorganizowane to być powinno. To dzięki nim każde święta zawsze wyglądają magicznie i zawsze mają ten sam zapach. Można ich nazwać naturalnymi nauczycielami tradycji i historii.

Zwykle to babcia wprowadzała wnuków w historię rodziny, opowiadała o krewnych, dbała o przekazywanie zwyczajów rodzinnych, podtrzymywała kult rodziny jako rodu. Dziadek stawał się historykiem i kronikarzem rodziny, przyjacielem dla starszego wnuka, a bohaterem dla młodszego. Był dla wnuków nauczycielem, który w pełni akceptuje swego młodszego partnera i na nim koncentruje całą swoją uwagę. Najcenniejsza we wzajemnych relacjach dziadków z wnukami była ich dialogowość i odgrywanie swoich ról w sposób oparty na więzi emocjonalnej. Siła tych więzi zapewniała poczucie bezwarunkowej miłości i bezpieczeństwa. Dziadkowie stali na straży szczęścia rodziny, bo to było dla nich najważniejsze. „Do podstawowych obowiązków starszego pokolenia wobec wzrastających dzieci jest ukazanie za- 
sad moralnych, które najogólniej płyną z nauki rozróżnienia między dobrem a złem i wybierania zawsze dobra, zgodnie z prawami natury"10. W czasach wielkiej gonitwy za sukcesem i pieniędzmi są ostoją spokoju i przypominają swoim dzieciom i wnukom, co jest w życiu najważniejsze.

Dzięki mądrości i doświadczeniu dziadków wnukowie mogą nauczyć się patrzenia na wiele spraw z innej perspektywy, dostrzec, co jest w życiu wartościowe, naprawdę ważne i trwałe, że hierarchia wartości jest potrzebna do tego, aby wytrwać w teraźniejszości i przyszłości. Dziadkowie wyprzedzają wnuków na drogach życia, od nich młodzi mogą się uczyć, jak radzić sobie z trudnościami, własną chorobą, ograniczeniami, jak przyjmować naturalne zmiany związane z procesem starzenia się ludzkiego organizmu, akceptować życie, jakie przeżyli. A gdy dojdą już do kresu swego życia, najstarsi uczą najmłodszych, jak umierać, jak się nie bać śmierci, jak ją przyjmować, jak rozstawać się z najbliższymi, ze światem. To najstarsi pokazują, że jest głęboki sens we wszystkich ludzkich doświadczeniach, jakie spotykają człowieka, i w tych przyjemnych, radosnych, i w tych trudnych, związanych z cierpieniem. „Zarówno małe dzieci, potrzebujące przewidywalności zdarzeń, jak i dorastający nastolatkowie poszukujący własnej tożsamości, a także młodzi dorośli borykający się z nowymi życiowymi wyzwaniami, mogą zyskać poczucie sensu życia w kontakcie z osobami, które już przeżyły dużą część swojego życia i potrafią dostrzec w nim pewien porządek, ład i sens"11.

Relacje dziadków z dziećmi, wnukami budują lojalność, troskliwość i zainteresowanie i pewną solidarność pokoleniową, którą Anna Zych określa jako „wzajemną zależność pokolenia wchodzącego na arenę życiową i odchodzącej generacji. Oznacza ona nie tylko wspieranie się, opiekę czy obopólną pomoc, ale także współdziałanie i współodpowiedzialność oraz zgodność w poglądach i dążeniach członków wspólnoty rodzinnej i najbliższych krewnych. Znaczy też solidarność

10 J. Śledzianowski, Dziadkowie z pomocq wnukom, w: Człowiek $w$ obliczu trudnej sytuacji życiowej, pod red. B. Kałdon, I. Kurlak, Sandomierz-Warszawa 2011, s. 183.

11 E. H. Erikson, Dopetniony cykl życia, tłum. A. Gomola, Poznań 2002, s. 122. 
konsensualną, która polega na wzajemnej zgodzie dotyczącej wiary i/lub wartości zewnętrznych w stosunku do rodziny, ale i solidarność funkcjonalną, która dotyczy wzajemnej wymiany pomocy i wsparcia o charakterze nie tylko instrumentalnym, lecz przede wszystkim emocjonalnym, a także solidarność normatywną, która dotyczy norm i oczekiwań w interakcjach, wyrażania pozytywnych emocji i szacunku, udzielania sobie nawzajem pomocy między generacjami"12.

Ważnym czynnikiem w relacjach dziadków z wnukami jest miejsce zamieszkania dziadków - czy mieszkają oni w jednym domu ze swoimi wnukami, czy też w zupełnie innym miejscu. Dziadkowie, którzy mieszkają w jednym domu z wnukami, stają się stałym elementem w życiu dziecka i nierozerwalną częścią rodziny. Dziadkowie niemieszkający z wnukami są osobami nieco rzadziej widywanymi i często przez to bardziej atrakcyjnymi ${ }^{13}$.

Helen Bee wymienia trzy typy związków między dziadkami a wnukami. Pierwszy to związek zdystansowany, gdy dziadkowie widują wnuki stosunkowo rzadko i mają niewielki wpływ na ich życie. Zdystansowanie to może być efektem fizycznego bądź/i emocjonalnego oddalenia. Dziadkowie o chłodnym stosunku do wnuków, zajęci swoimi sprawami, to około 29\% populacji. Anna Brzezińska nazywa ich „dziadkami - dalekimi krewnymi”. Zwykle są oni bardziej skoncentrowani na swoim życiu, zdrowiu, zainteresowaniach, pracy, karierze, własnych przyjemnościach niż na opiece i trosce o młodsze pokolenie. Drugi to związek zaangażowany, kiedy dziadkowie podejmują się współwychowanka wnuków i są aktywnie zaangażowani w opiekę nad nimi, pomagając pracującym rodzicom. Takie związki często występują w rodzinach wielopokoleniowych, które mieszkają wspólnie i stanowią ok. 16\% relacji. Trzeci związek to „związek towarzyski”, ponieważ tworzą go dziadkowie budujący bardzo ciepłe relacje ze swoimi wnukami. Kochają ich, poświęcają im dużo czasu, rozpieszczają, ale nie podejmują obowiązków, które są związane z wychowaniem.

12 A. Zych, Przekraczając smuge cienia. Szkice z gerontologii i tanatologii, Katowice 2009, s. 123.

13 Por. K. Appelt, A. Brzezińska, Dziadkowie dobrzy na wszystko, „Charaktery" 2006, nr 1, s. 31-33. 
Starają się oni zachować równowagę między troską o siebie a młodsze pokolenie. „Dziadkowie - towarzysze”, bo tak zostali nazwani, stanowią najliczniejszą grupę, około 55\% populacji dziadków ${ }^{14}$.

Katarzyna Appelt za Williamem Bengstonem opisuje natomiast cztery role, które dziadkowie mogą odgrywać w swoich rodzinach. Po pierwsze, mogą być „kotwicą” - stanowić stały punkt odniesienia, ważny w czasach gdy rodzina doświadcza kłopotów albo podlega zmianie, np. rozwód. Po drugie, dziadkowie mogą być „ochroniarzami” stojącymi na straży trwałości rodziny, zapewniając ochronę i opiekę w niebezpieczeństwie, stanowią wsparcie, gdy np. ktoś doświadcza problemów finansowych czy problemów związanych z pracą. Trzecia rola to „arbiter”. Pełniący tę funkcję dziadkowie pomagają w sporach między drugim a trzecim pokoleniem, czyli między rodzicami a dziećmi, odgrywają rolę negocjatorów w trakcie konfliktów. Pomagają także wnukom w zrozumieniu zachowań ich rodziców. Dziadkowie są także „rodzinnymi historykami”, pomagają zrozumieć zależności między przeszłością a teraźniejszością ${ }^{15}$.

W dzisiejszym świecie relacje te uległy załamaniu i wciąż podlegają dalszej destrukcji. Wszyscy ludzie na ziemi stali się częścią zdezintegrowanego systemu przepływu informacji, opartego na wynalazkach elektronicznych, młodzi ludzie w każdej części świata stają przed sytuacją, z którą nikt ze starszych nie spotkał się dotąd. I odwrotnie, starsze pokolenie nie może już liczyć na to, że w życiu ich dzieci powtórzy się ich własne, nieznane nikomu przez nimi doświadczenie stopniowo ujawniającej się zmiany.

Problem rozdźwięku między twórcą a użytkownikiem znany jest w literaturze jako luka ludzka (human gap) i opisany w raporcie Klubu Rzymskiego ${ }^{16}$. Luka ludzka to dystans między rosnącą złożono-

14 Por. H. Bee, Psychologia rozwoju człowieka, tłum. A. Wojciechowski, J. Gilewicz, Poznań, 2009, s. 513-514; A. Brzezińska, Niezbędność dziadków, „Charaktery" 2001, nr 5 (52), s. 27-29.

15 Por. K. Appelt, Wspótcześni dziadkowie i ich znaczenie dla rozwoju wnuków, w: Szanse rozwoju w okresie późnej dorosłości, pod red. A. Brzezińskiej, K. Ober-Łopatki, R. Stec, K. Ziółkowskiej, Poznań 2007, s. 79-95.

16 Por. J. W. Botkin, M. Elmandjra, M. Malitza, Uczyć się - bez granic. Jak zewrzeć „lukę ludzką”, tłum. M. Kukliński, Warszawa 1982, s. 33-34; J. Morbitzer, 
ścią świata a naszą zdolnością do postrzegania jej. Dzisiejsza złożoność świata wynika głównie z działalności ludzkiej. Luka ludzka ma charakter rozłamu powstającego dlatego, że za wzrostem tworzonych przez ludzi komplikacji nie podąża postęp naszych umiejętności. Niezależnie od posuniętego zaawansowania w innych dziedzinach, żyjący współcześnie ludzie nie są jeszcze w stanie w pełni zrozumieć powodowanych przez samych siebie zmian w środowisku naturalnym i we własnym położeniu, coraz bardziej oddalają się od realnego świata. Przez lukę ludzką rozumie się więc brak zdolności adaptacyjnych u niektórych ludzi do skomputeryzowanej rzeczywistości i rodzenie się stanów frustracji z przekonania, że są coraz gorzej przygotowani do wykorzystywania w pracy nowoczesnych technik. Konstruowane coraz doskonalsze systemy informatyczne wymagają coraz lepiej przygotowanych użytkowników i często w relacji człowiek-technika zawodzi to pierwsze ogniwo ${ }^{17}$.

Przeciętny dorosły nie radzi sobie z techniką, którą sam stworzył, nie do końca ją rozumie i nie zawsze potrafi sprawnie się w tym świecie poruszać. Natomiast przeciętne dziecko radzi sobie w nim znakomicie, błyskawicznie opanowuje wszelką potrzebną mu wiedzę i umiejętności. Zdarza się, że jest ono bardziej związane z globalnym dzieckiem, żyjącym na drugim krańcu świata, niż ze starszymi osobami w rodzinie. Globalne dziecko jest pragmatyczne, łatwo się komunikuje, jest tolerancyjne dla różnicy i odmienności, a jednocześnie cechuje go sceptycyzm wobec idei zaangażowania i głębszego uczestnictwa w jakimkolwiek przedsięwzięciu.

\section{Rekomendacje - możliwości re-konstrukcji dialogu pokoleń dzięki urządzeniom mobilnym}

W tekście celowo nie użyto sformułowania „rekonstrukcja”, czyli odbudowa pierwotnej wersji jakiegoś dzieła, ponieważ nie jest już moż-

Rozważania o nietechnologicznych celach technologii informacyjnej, w: Komputer $w$ edukacji, pod. red. J. Morbitzera, Kraków 2008, s. 147-155.

17 Por. J. Olędzki, Komunikowanie w świecie. Narzędzia, teorie, unormowania, Warszawa 1998, s. 21. 
liwy powrót do uprzednich relacji osobowych, opartych na osobistym przekazywaniu wiedzy przez starsze pokolenia i wyznaczania tym samym drogi dzieciom i młodym ludziom. Świat zmienia się w sposób dynamiczny, młode pokolenia wchodzą w swoje życie według innych niż dotychczas zasad i reguł i tego zjawiska nie da się już zatrzymać. Wykorzystano słowo „re-konstrukcja”, które autorka rozumie jako skonstruowanie tych relacji na nowo, według innych zasad, tych, które rządzą dzisiejszym światem i społeczeństwem, z uwzględnieniem dostępnych środków technicznych.

W takim kontekście w kulturze prefiguratywnej można dostrzec nowe możliwości. Zmiany zachodzą w niej bardzo szybko, a zadaniem osób uczestniczących w jej kreowaniu jest szybkie odpowiadanie i reagowanie na te zmiany. Konieczne jest dostosowywanie się do otoczenia, nastawionego na rozwój i tworzenie nowych technologii, pomocnych w codziennym życiu człowieka. Celem działania jest szukanie nowych dróg funkcjonowania w świecie zgodnie z założeniem, że ze starych rozwiązań już nie można korzystać. Następuje zanik tradycyjnych autorytetów, gdyż okazuje się, że pokoleniem „mądrzejszym” jest pokolenie młodych i to od nich starsi powinni się uczyć, jak funkcjonować w społeczeństwie stworzonym $\mathrm{w}$ taki sposób, że tylko młodzi potrafią się w nim sprawnie poruszać. Młodsi są dla starszych wzorem dla naśladowania. Powinno więc dojść do osiągnięcia nowej formy komunikacji pomiędzy pokoleniami, w której młode pokolenie nauczy się porozumiewać z dorosłymi, ucząc ich nowych form rozwiązań, natomiast dorośli muszą być gotowi do przyjęcia nauk od pokolenia młodszego, które chce się rozwijać18.

Dziś należy zmienić wychowanie dorosłych, tak aby móc zapomnieć o postfiguratywnym wychowaniu z zawartymi w nim kofiguratywnymi komponentami i odkryć prefiguratywne sposoby uczenia się i przekazywania wiedzy. Trzeba stworzyć nowe wzorce dla dorosłych, którzy powinni nauczyć dzieci nie tego, czego powinny się uczyć, lecz tego, jak powinny się uczyć, i nie tego, z czym się powinny identyfikować, ale tego, jaką wartość ma identyfikacja. Wydaje się, że jednym

18 Por. E. Karmolińska-Jagodzik, Komunikacja międzypokoleniowa - rozważania wokół różnic kulturowych, „Studia Edukacyjne” 2012, nr 21, s. 196-197. 
skutecznym oddziaływaniem w tym zakresie jest powrót do systemu rodziny wielopokoleniowej, niekoniecznie mieszkającej wspólnie, lecz raczej utrzymującej dość ścisłe kontakty i relacje oparte na bliskości emocjonalnej. W jaki sposób jednak dokonać tej sztuki, zważywszy na odmienność światów młodego i starszego pokolenia, odmienność sposobów komunikowania i przeżywania zastanej rzeczywistości?

W świecie kultury prefiguratywnej konieczne wydaje się włączenie dzieci i osób młodych do systemu pozaformalnej edukacji - nie jako uczniów, lecz „nauczycieli”. To właśnie dzieci, błyskawicznie nabywające kompetencji w posługiwaniu się nowoczesnymi technologiami (w tym urządzeniami komunikacji mobilnej), mogą z łatwością pomóc osobom starszym opanować nowe, konieczne w dzisiejszym świecie umiejętności. Sam „odwrócony” proces tej edukacji stwarza niezwykłe możliwości osobistych, bliskich kontaktów w ramach „nauczania indywidualnego", odnowienia dialogu i relacji. Dziecko nabiera przy tym szczególnej pewności siebie, poczucia własnej wartości jako ten „mądrzejszy” uczestnik procesu nauczania - uczenia się, co w pewnym stopniu zaspokaja jego dążenie do „dorosłości”, potrzebę uznania i odczuwania własnego rozwoju. Doświadcza też szczególnego zainteresowania ze strony dorosłych - nie jako dziecko ze swym dziecięcym światem i jego problemami, ale jako ten, którego kompetencje są doceniane i podziwiane. Mając w dziadkach wdzięcznych i uważnych słuchaczy, otwartych na nową wiedzę, przekazywaną im od podstaw i z dziecięcą logiką, dzieci potrafią uczyć ich z niezwykłą cierpliwością, której nie przejawiają wobec swoich rodziców - zawsze zajętych i „zabieganych” i dążących w takich sytuacjach jedynie do rozwiązania bieżącego problemu.

Nauka posługiwania się urządzeniami nowoczesnych technologii przynosi nowe możliwości dla osób starszych - odnalezienia się w „mobilnym świecie” i w miarę sprawne poruszanie się w nim - bieżącego dostępu do informacji, posługiwania się skrzynką mailową, korzystania z portali społecznościowych czy aplikacji, umożliwiających komunikowanie się w czasie rzeczywistym za pośrednictwem głosu i obrazu. W ten sposób starsze pokolenie zaczyna dostosowywać się do nowego otoczenia, mija lęk przed dynamicznymi zmianami rzeczywistości i poczucie marginalizacji. 
Opanowanie nowych kompetencji funkcjonowania w mobilnym świecie umożliwia też re-konstrukcję dialogu z młodym pokoleniem (dziećmi, wnukami) na nowych warunkach i za pomocą nowych narzędzi. Możliwość bezpośredniej komunikacji nawet ze znacznej odległości stwarza nową szansę na odzyskanie przez starsze pokolenie choćby częściowego wpływu na funkcjonowanie w świecie i sposób myślenia młodych, na przekazywanie wartości i rodzinnej historii. Posługiwanie się kanałem komunikacyjnym, akceptowanym i najczęściej wykorzystywanym przez dzieci i młodzież jest w stanie przekonać tychże do podjęcia tych relacji, a nierzadko do samodzielnego ich inicjowania. Nowoczesne urządzenia poprzez wykorzystanie dźwięku i obrazu w komunikacji dają namiastkę obecności, fizycznej bliskości partnera rozmowy, co w relacjach dzieci-dziadkowie jest niezwykle istotne ze względu na globalne, polisensoryczne doświadczanie świata i drugiej osoby.

Dzięki więc nowoczesnym technologiom, które wydają się wyłączać starsze pokolenie z udziału w życiu rodzinnym i wychowywaniu najmłodszych może w rzeczywistości nastąpić zbliżenie kolejnych pokoleń. Negocjowanie kształtu współczesnej rzeczywistości rodzinnej, w wysokim stopniu skupionej na mobilności, dzięki chęci i aktywności osób starszych w uczeniu się nowych kanałów komunikacyjnych może w efekcie doprowadzić do pozytywnego skutku zmniejszania pustki i przestrzeni międzygeneracyjnej.

\section{Streszczenie}

RE-KONSTRUKCJA DIALOGU POKOLEŃ

W RZECZYWISTOŚCI KULTURY PREFIGURATYWNEJ

Pokolenie dziadków zwykle stanowiło źródło wartości i wzorów kulturowych, byli oni przewodnikami po świecie dla swoich wnuków, pośrednikami między przeszłości, a czasami obecnymi. W nowoczesnym społeczeństwie dzieci zaczęły żyć własnym życiem, źródłem wzorów stały się przede wszystkim media, a nieumiejętność poruszania się starszych ludzi w tym obszarze 
zablokowała możliwość przekazywania doświadczenia i mądrości poprzednich pokoleń. Jednak kultura prefiguratywna niesie ze sobą $\mathrm{w}$ tym zakresie pewne szanse - to dzieci stają się nauczycielami i przewodnikami starszych ludzi po świecie mediów i nowoczesnych technologii, a nawiązywany przez nich często za pomocą tych technologii kontakt umożliwia - dzięki właśnie nowym umiejętnościom starszego pokolenia - przywrócenie im naturalnej roli przekazicieli tradycyjnych wartości i wzorców, szanujących jednak specyfikę funkcjonowania dzieci w medialnej rzeczywistości.

Słow a kluczowe: kultura prefiguratywna; dialog pokoleń; dzieci; media

\section{Summary}

\section{RE-CONSTRUCTING THE DIALOGUE}

OF GENERATIONS AGAINST THE REALITY OF PREFIGURATIVE CULTURE

Generations of grandparents were usually a source of values and cultural patterns, they were the guides in the world to their grandchildren, intermediaries between the past and present. In modern society children began to live their own lives, the source of patterns became primarily the media. The inability to move older people in this area has blocked the possibility of transferring the experience and wisdom of previous generations. However, prefigurative culture brings with it some chances - children become teachers and leaders of older people in the world of media and modern technology. Ongoing contact with children, often through these technologies, enables the older generations to bring back the older generations with the natural role of communicating traditional values and patterns that respect the specificities of children's functioning in the media world.

Keywords: prefigurative culture; dialogue between generations; children; media 